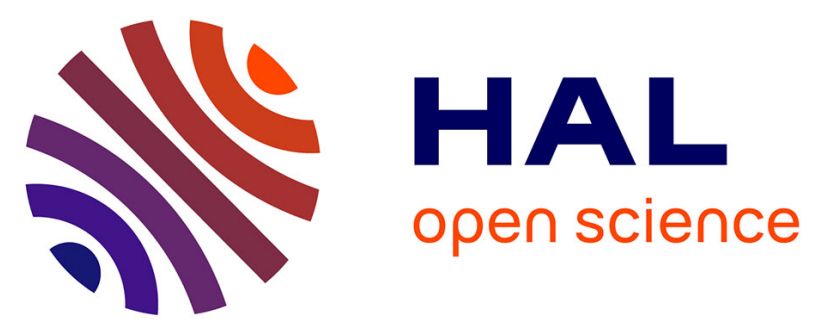

\title{
Methodology for using the MOZAIC ozone climatology in the future comparisons with data from SCIAMACHY onboard ENVISAT
}

Régina Zbinden, Bastien Sauvage, Valérie Thouret, Philippe Nédélec, Gilles Athier, Jean Pierre Cammas, Jean-Luc Attié

\section{To cite this version:}

Régina Zbinden, Bastien Sauvage, Valérie Thouret, Philippe Nédélec, Gilles Athier, et al.. Methodology for using the MOZAIC ozone climatology in the future comparisons with data from SCIAMACHY onboard ENVISAT. Springer Verlag. Sounding the Troposphere from Space: a new Era for Atmospheric Chemistry. The TROPOSAT Final Report., Heidelberg, pp.355-360, 2003, 10.1007/978-3642-18875-6_42 . hal-00199436

\section{HAL Id: hal-00199436 \\ https://hal.science/hal-00199436}

Submitted on 13 Sep 2021

HAL is a multi-disciplinary open access archive for the deposit and dissemination of scientific research documents, whether they are published or not. The documents may come from teaching and research institutions in France or abroad, or from public or private research centers.
L'archive ouverte pluridisciplinaire HAL, est destinée au dépôt et à la diffusion de documents scientifiques de niveau recherche, publiés ou non, émanant des établissements d'enseignement et de recherche français ou étrangers, des laboratoires publics ou privés. 


\title{
Methodology for Using the MOZAIC Ozone Climatology in Future Comparisons with Data from SCIAMACHY Onboard ENVISAT
}

\author{
Régina Zbinden, Bastien Sauvage, Valérie Thouret, Philippe Nédélec, \\ Gilles Athier, Jean Pierre Cammas and Jean Luc Attié. \\ Laboratoire d'Aérologie, Observatoire Midi-Pyrénées, Toulouse, France \\ e-mail : thov@aero.obs-mip.fr
}

\section{Summary}

The MOZAIC program was designed to collect ozone and water vapour data, using automatic equipment installed on board five long-range Airbus A340 aircraft flying regularly all over the world since August 1994 (Marenco et al. 1998). From ozone data recorded at cruise levels during a 2-year period (September 1994 to August 1996), the first accurate ozone climatology at 9-12 km altitude has been generated (Thouret et al.1998a). From now on, we are providing different "elaborated" products such as the tropospheric ozone columns and the horizontal climatology with data referred to the tropopause altitude. We have chosen to use the tropopause altitude as the reference to get rid of its seasonal variations. Thus, we have access to the upper tropospheric ozone and to the lower stratospheric ozone distributions. In this first approach, we have chosen only to represent and analyse the measurements recorded at mid northern latitudes. In this study, we defined the tropopause as a mixing zone $30 \mathrm{mb}$ thick centred on the surface PV $=2 \mathrm{PVU}$. Another set of climatologies is now available for the levels "tropopause $\pm 15 \mathrm{mb}^{\prime}$ and "tropopause $\pm 45 \mathrm{mb}$ ". In the frame of TROPOSAT, this new set of climatologies demonstrates that we have started a development for future comparisons with the SCIAMACHY instrument, for example. The 8 first years of the MOZAIC program has allowed a first assessment of the inter-annual variability of ozone both in the free troposphere and in the UT/LS to be made. The results are surprisingly high (about $2 \% / y e a r)$. The year 1998 appears as a positive anomaly. Further studies have started to explain such a high increase of ozone in the troposphere and the lower stratosphere at northern mid-latitudes. 


\section{Introduction}

Ozone observations made by the five A340 aircraft involved in the MOZAIC program extend now over almost 8 years (since August 1994) corresponding to about 19,000 flights (Marenco et al. 1998). For recent details, see the web site http://www.aero.obs-mip.fr/mozaic/. The overall aim of the program is to improve our understanding, both physical and chemical, of the atmosphere and hence to help evaluate the atmospheric impact of aircraft and other anthropogenic emissions through an extended validation of the existing three-dimensional (3-D) chemistry and transport models (CTM). From data recorded at cruise levels during a 2-year period, (September 1994 to August 1996), the first accurate ozone climatology at 9-12 km altitude had been generated (Thouret et al. 1998a). The climatology based on these high quality data had been compared to the climatology issued from the ozone sounding network and the results were very good (Thouret et al. 1998b), thus defining the MOZAIC data as the expected complement to this network. The MOZAIC data are of particular interest for many studies (e.g. 3-D model validation, regional analyses) and they are particularly valuable in describing, densely and regularly, the upper troposphere and lower stratosphere region (UT/LS).

In the frame of this project, the MOZAIC ozone data have been compiled to produce horizontal and vertical distributions of tropospheric and lower stratospheric ozone. The Tropospheric Ozone Columns (TOC) have been calculated over the main airports visited by the program, especially for the northern mid-latitudes where the troposphere has been entirely sampled. In the UT/LS region, we have computed the data to get a new set of climatologies characteristic of the UT and the LS separately (i.e. independently of the seasonal variations of the tropopause altitude). Given that we have 8 years of recorded data, we have started to assess the inter-annual variabilities of the ozone distribution in the free troposphere (Zbinden et al. 2003).

\section{Objectives}

In the context of TROPOSAT, our work has to be seen as a strategy development for a methodology to be used in the frame of the future comparisons studies between MOZAIC and the SCIAMACHY data $\left(\mathrm{O}_{3}\right.$ and $\left.\mathrm{CO}\right)$. Our activity during the year 2001 concerned the calculations of: 1) the Tropospheric Ozone Columns (TOC) over the main airports documented by the MOZAIC aircraft at mid northern latitudes, and 2) the new set of $\mathrm{O}_{3}$ climatologies in the UT/LS region for the mid-northern latitudes (North Atlantic region only) representing tropopause scaled data (see previous report for details). Our main objective for the year 2002 has been to update our previous work with the additional measurements and PV calculations as well as developing the analysis to understand better the a high ozone increase we observed in our data set between 1994 and 2002. 


\section{Activities}

Our activity during the year 2002 has been dealing with :

1 re-calculations of the tropospheric ozone columns over the main airports documented by the MOZAIC aircraft at mid-northern latitudes using the PV values along each flight track as calculated by CNRM.

The PV values (1.5, 2, 3 or 4 PVU) are used to locate the tropopause. Thus the TOC are calculated avoiding using any ozone threshold as had been done previously. We obtained the time series for five well documented airports between August 1994 and July 2000 at mid-northern latitudes: Frankfurt (5270 profiles), Paris (2898 profiles), New York (2144 profiles), Vienna (2078 profiles) and Japan (Tokyo, Osaka, Nagoya, 1454 profiles) characterising the ozone distribution in the troposphere. Fig. 5.8.1 gives an example of the seasonal cycle of the TOC over Frankfurt (the most documented MOZAIC airport). Note that this plot results fiom at least 1 profile per day since August 1994 (i.e. much higher fiequency than a sonde network is able to produce). Then we have started to calculate the seasonal variations and the inter annual variabilities. After the levelling off recorded at the beginning of the nineties, the tropospheric ozone distribution again shows an increase of about $2 \%$ per year (Fig. 5.8.1). The increase is especially obvious from and after 1997; moreover, it is more pronounced in winter than in summer thus characterising an increase of the background concentrations instead of an enhanced photochemical activity. Differences between maximum values in summer and minimum values in winter exceed $10 \mathrm{DU}$. The negative anomaly during the winter of 1996 and the positive anomaly during the summer of 1998 are being investigated.

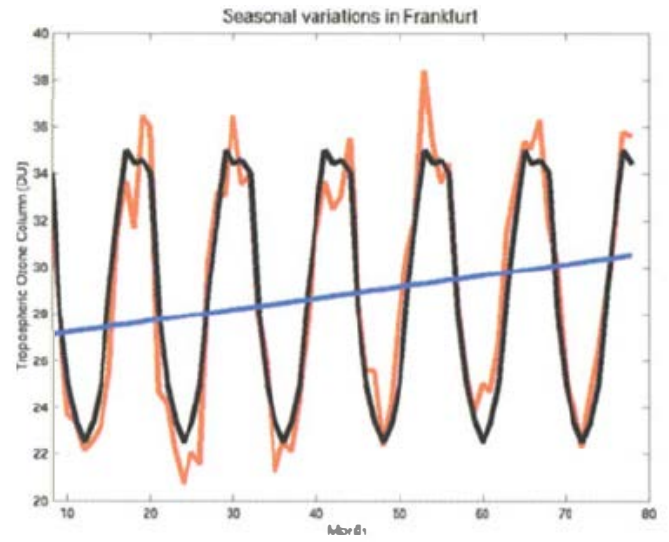

Fig. 5.8.1. Seasonal variations of the tropospheric ozone column (DU) in Frankfurt from MOZAIC data from August 1994 to June 2010. Black line: average seasonal variations over the period 1994-2000. Red line: Monthly means. Blue line: linear fit showing an average increase of $2 \%$ per year over the whole period. 
The average increase of $2 \%$ per year is probably an overestimation of the actual ozone trend because the period of the MOZAIC data base is still too short to extract a long term trend of ozone. Continuing MOZAIC measurements will allow us to assess actual ozone trends much more accurately.

2 the new set of $\mathrm{O}_{3}$ climatologies in the UT/LS region for the mid-northern latitudes (North Atlantic region only) up to February 2002.

From now on, we have chosen to use the tropopause altitude as the reference. Therefore we have the ozone distributions in both the upper troposphere (UT) and the lower stratosphere (LS) regardless the seasonal variations of the tropopause. The colour figures cannot be shown here. Further details concerning the elaborated PV calculations (space and ime interpolations) as well as our original ropopause definition and these new ozone distributions maps will be given in Thouret et al. (2003) (see previous report for a short summary).

One of the main interesting features that appeared in these time series in the UT/LS is what we called the "1998 anomaly". Enhanced concentrations, about $10 \%$ higher than the three previous years, were recorded in 1998 in both the UT and the LS (Fig. 5.8.2). Our main activity in 2002 has been to understand why such an increase has been observed in this region. Different hypotheses have been and are still being tested, such as the effect of the intensive boreal fires in 1998, the effect of the North Atlantic Oscillation, etc...
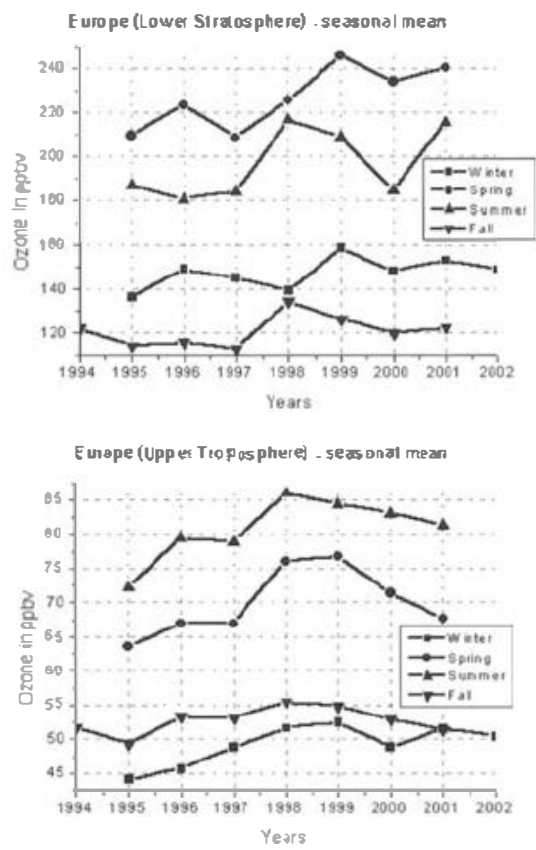

Fig. 5.8.2. Ozone seasonal means in the UT/LS over Europe (30-55 ${ }^{\circ} \mathrm{N}$ and $25^{\circ} \mathbf{E}-10^{\circ} \mathrm{W}$ ). Winter is DJF. 


\section{Conclusions}

The different presentations of the data we have developed are going to be very useful in our future work. It will be absolutely necessary to compare the climatologies issued from different sensors onboard the satellites such as MOPITT or SCIAMACHY to be sure that the tropospheric and stratospheric columns calculated from space are in agreement with those calculated (even partly) from in-situ measurements. The MOZAIC program data are providing dense and regular in-situ measurements in many regions not well sampled by some other campaigns or sounding network. The UT/LS region is indeed of particular interest (note that the North Atlantic Flight Corridor and adjacent continents has been sampled every day for 8 years). We are now able to provide an accurate ozone distribution analysis around the tropopause and throughout the troposphere over tens of cities at mid-latitudes and subtropics. We are also working on the understanding of what causes the inter-annual variabilities and their regional differences.

\section{Aims for the future}

Our objective for 2003 and beyond is to keep developing "elaborated" products (like tropospheric columns and climatology referred to the tropopause altitude) and to start a detailed analysis of the comparison between the MOZAIC $\left(\mathrm{O}_{3}\right.$ and $\mathrm{CO}$ ) climatologies and the equivalent distributions derived from MOPITT/TERRA and SCIAMACHY/ENVISAT.

Concerning the validation activity, we propose to compare operational $\mathrm{CO}$ related radiances (level 1 from various instruments) with model-calculated radiances using MOZAIC data. As well as this, we will compare the MOZAIC $\mathrm{O}_{3}$ and $\mathrm{CO}$ distributions with the "probed from space" distributions (level 2 from various instruments).

Relative to the scientific objectives, we will combine the measurements provided by the various instruments in the UT/LS region together with MOZAIC data in order to improve our understanding of the distribution and the budget of the tropospheric ozone and its precursors. Our domains of interest are:

- stratosphere-troposphere exchanges: tropopause folding processes at midlatitudes or Rossby wave breaking processes in subtropics

- ozone and carbon monoxide distribution and variability in the UT/LS region

- intercontinental transport of $\mathrm{CO}$ to highlight the different sources such as biomass burning and industrial pollution, and

- modelling and assimilation studies of $\mathrm{CO}$ and $\mathrm{O}_{3}$ from SCIAMACHY (and others) in the non hydrostatic meso-scale MESO-NH chemistry model coupled to the CTM MOCAGE. 


\section{Acknowledgements}

We thank Air France, Austrian Airlines, Lufthansa, and Sabena for carrying free of charge the MOZAIC equipment on scheduled flights. We sincerely thank the European Union for funding the MOZAIC program.

\section{References}

Marenco A, V Thouret, P Nédélec, H Smit, M Helten, D Kley, F Karcher, P Simon, K Law, J Pyle, G Poschmann, R Von Wrede, C Hume, T Cook (1998) Measurement of ozone and water vapor by Airbus in-service aircraft: The MOZAIC airborne program, An overview, $J$ Geophys Res 103:25,631-25,642.

Thouret V, A Marenco, P Nédélec, C Grouhel (1998a) Ozone climatologies at 9-12 km altitude as seen by the MOZAIC Airborne Programme between September 1994 and August 1996, J Geophys Re. 103:25,653-25,679.

Thouret V, A Marenco, J Logan, P Nédélec, C Grouhel (1998b) Comparisons of ozone measurements from the MOZAIC airborne programme and the ozone sounding network at eight locations, $J$ Geophys Res 103:25,695-25,720.

Thouret V, J-P Cammas, B Sauvage, G Athier, R Zbinden, P Nédélec, P Simon (2003)ropopause referenced ozone climatology and inter-annual variability (19942002) from the MOZAIC program. J Geophys Res submitted.

Zbinden $\mathrm{R}$ et al (2003) First assessment of the inter annual variabilities of the ozone distribution in the free troposphere, submitted. 